\title{
ARAŞTIRMA/RESEARCH
}

\section{Polikistik over sendromunda over volümü ölçümü ve metabolik değerlendirme: kesitsel gözlemsel çalışma}

\author{
Metabolic evaluation and measurement of ovarian volume in polycystic ovary \\ sydrome: a cross-sectional observational study
}

\author{
Mehtap Evran ${ }^{1}$, Hüseyin Tuğsan Ballı², Murat Sert ${ }^{1}$, Bekir Tamer Tetiker ${ }^{1}$ \\ ${ }^{1}$ Çukurova Üniversitesi Tıp Fakültesi İç Hastalıkları Anabilim Dalı, Endokrinoloji ve Metabolizma Bilim Dalı, ${ }^{2}$ Radyoloji \\ Anabilim Dalı, Adana, Turkey
}




cholesterol level was below $50 \mathrm{mg} / \mathrm{dl}$ in 15 (68\%) patients. In abdominal ultrasonography, mean ovarian volumes were $11.6 \pm 1.12 \mathrm{ml}$ on right, $11.5 \pm 1.01 \mathrm{ml}$ on left. 13 $(59.1 \%)$ patients had polycystic ovary appearance.

Conclusion: Hirsutism was detected in all of our patients. In most of them, polycystic ovary sydrome diagnosis was supported by cycle irregularity, increased ovarian volume and polycystic ovary appearance in ultrasonagraphy. In ou polycystic ovary sydrome patients, hyperandrogenism laboratory findings, insulin resistance and obesity were seen in lower ratios.

Key words: Polycystic ovary sydrome, ovarian volume, insulin resistance.

\section{GİRİ̧̧}

Polikistik over sendromu (PKOS) üreme çağındaki kadınlarda prevalansı \%5-10 civarında olan önemli bir sorundur1. Hastalarda hiperandrojenizm, kronik anovulasyon ve infertiliteye yol açabilir ${ }^{2}$. Polikistik over sendromu etyolojisinde familyal ve genetik faktörler rol oynar ${ }^{3}$. Ancak patogenezde esas faktör insülin direncidir ve PKOS hastalarında insülin direnci normal populasyona göre 2-3 kat daha yüksektir ${ }^{4}$.

PKOS'lu kadınlarda insülin direnci ve adipozite artışı diyabetes mellitus (DM), hipertansiyon, dislipidemi, kardiyovasküler hastalıklar ve endometriyal kanser için risk oluşturmaktadır ${ }^{2,5}$. Tanı tipik olarak klinik belirtilere (düzensiz mentrüel sikluslar, hirsutizm ve akne) dayanmakla beraber biyokimyasal testler ve ultrasonografik incelemeyle ek bilgiler elde edilebilmektedir ${ }^{1}$. Erken tan 1 ve metabolik hastalıkların tedavisi temel yaklaşım olmalıdır. Tedavide yaşam şekli değişiklikleri ile birlikte dengeli bir beslenme, kilo verme, düzenli egzersiz çok önemlidir. İlaç tedavisinde antiandrojenik ilaçlar, oral kontraseptif ajanlar ve/veya insülin duyarlılığını artırıcı metformin kullanımı temel yaklaşımları oluşturmaktadır 3,6 .

$\mathrm{Bu}$ çalışmamızda PKOS tanısı ile izlediğimiz hastaların klinik ve metabolik özelliklerini ve ultrasonografik değerlendirmelerini sunmayı amaçladık.

\section{GEREÇ VE YÖNTEM}

Çalışmaya Endokrinoloji polikliniğimize 3 aylık süre boyunca başvuran ve hirsutizm, adet düzensizliği gibi semptomları olan hastalardan PKOS düşünülen 22 kadın hasta alındı. Çalışma için yerel etik kurul onayı ve hastalardan aydınlatılmıs gönüllü olur ile AST, ALT ve GGT düzeyleri normal bulunurken, 15 (\%68) hastada HDL kolesterol $50 \mathrm{mg} / \mathrm{dl}$ altındaydı. Abdominal ultrasonografide over volümleri ortalama sağda $11.6 \pm 1.12 \mathrm{ml}$, solda $11.5 \pm 1.01 \mathrm{ml}$ ölçüldü ve 13 hastada (\%59.1) polikistik over görünümü mevcuttu.

Sonuç: Hastalarımızın tamamında hirsutizm saptanırken, büyük kısmında siklus düzensizliği, ultrasonografide over volümü artışı ve $\mathrm{PKO}$ görünümü ile PKOS tanısı desteklenmiştir. Ancak PKOS hastalarımızda laboratuar olarak hiperandrojenizm bulguları, insülin direnci ve obezite daha az oranda görülmüştür.

Anahtar kelimeler: Polikistik over sendromu, over volümü, insülin direnci

formu alındı. PKOS tanısı yeniden gözden geçirilmiş 2003 Rotterdam konsensus kriterlerine göre konuldu ${ }^{7}$. Hastaların yaşı, PKOS fenotipleri, ilk adet yaşı, siklus düzeni, doğum ağırlığ1 kaydedildi. Fizik muayene bulgularından vücut ağırlı̆g1 $(\mathrm{kg})$ ve boy (m) ile vücut kitle indexi $(\mathrm{kg} / \mathrm{m} 2)$, sistolik ve diyastolik kan basıncı ( $\mathrm{mmHg}$ ) ve hirsutizm için Ferriman\&Gallwey (FG) skorlaması (7 ve üstünde olması hirsutizm) kaydedildi. Siklus uzunlukları; 27 34 gün: A, 35-44 gün: $B$, 45-90 gün: $C$ ve 90 günden uzun: D grubu olarak kaydedildi. Hastaların PKOS için fenotipik özellikleri 'Hiperandrojenemi ve PKOS Derneğì" PKOS kriterlerine ${ }^{8}$ göre sinıflandırıldı:

Fenotip A: Oligomenore+ hiperandrojenizm+ polikistik overler (PKO),

Fenotip B: Oligomenore+ hiperandrojenizm

Fenotip C: Hiperandrojenizm + PKO

Fenotip D: Oligomenore $+\mathrm{PKO}$

Hastalarda 12 saatlik açlık sonrası sabah 08.0008.30'da EDTA'lı ve düz biyokimya tüpüne alınan kan örnekleri alınarak bu örneklerden serum elde etmek için ilk 1 saat içinde 4000 rpm'de 5 dakika santrifüje tabi tutuldu. Elde edilen serum örneğinden bekletilmeksizin glukoz $(70-105 \mathrm{mg} / \mathrm{dl})$, trigliserid $(<200 \mathrm{mg} / \mathrm{dl})$, LDL kolesterol $(<160 \mathrm{mg} / \mathrm{dl})$, HDL kolesterol (40-60mg/dl), AST (15-41U/L), ALT (1454U/L), GGT (7-50U/L) testleri Beckman DXC 800 biyokimya otoanalizöründe EnzimatikFotometrik yöntemle çalışıldı. Hastalarda CRP (0$0.8 \mathrm{mg} / \mathrm{dl})$ testi Beckman Image 800 otoanalizöründe Nefelometrik yöntemle çalışıldı. Hormonlardan total testosteron (kadınlarda 0.140.76ng/ml), Dehidroepiandrosteron-sülfat (DHEAS) (106-464 ng/ml), insülin (1.9-23 $\mu \mathrm{U} / \mathrm{ml})$, TSH $(0.34-5.6 \mu \mathrm{U} / \mathrm{ml})$ ve f T4 $(0.61-1.12 \mathrm{pg} / \mathrm{ml})$ Beckman DXI 800 immunoassay otoanalizöründe kemilüminesans yöntemiyle çalışıldı. Hastaların 17OH-Progesteron (17-OHP) ölçümü için alınan 
serum örneği -20 derecede dondurularak 3 ay içinde çözülüp toplu olarak ELISA yöntemiyle çalışıldı. 17OHP'un erken folliküler fazda $<2-3 \quad \mathrm{ng} / \mathrm{ml}$ bulunması ile klasik olmayan tipte konjenital adrenal hiperplazi ekarte edildi ${ }^{9}$. Kan sayımı testi ise EDTA'lı tüpe alınan örneklerden 2 saat içerisinde Beckman Coulter LH 780 otoanalizöründe Elektrikli Empedans yöntemiyle çalışıldı.

İnsülin direnci değerlendirmesi için Homeostaz model değerlendirme (HOMA-IR) yöntemi kullanıldı ve HOMA $\geq 2.24$ bulunması insülin direnci olarak kabul edildi ${ }^{10}$. Hastalarda over volüm ölçümleri ve karaciğer değerlendirmeleri abdominal ultrasonografi (US) ile (GE, UPG 1.5 SIGNA LX TO EXCITA) yapıldı. Verilerin istatiksel analizi SPSS 16 programı kullanılarak yapıldı. Tanımlayıcı değerlendirmeler ve sıklık analizleri yapıldı. $\mathrm{p}<0.05$ istatistiksel olarak anlamlı kabul edildi.

\section{BULGULAR}

Çalışmaya yaş ortalaması 21.41 \pm 0.88 (min:15max:31) olan 22 kadın hasta alındı. Polikistik over sendromu (PKOS) için fenotipik özellikleri değerlendirildiğinde hastaların \%40.9'u B, \%31.8’i C ve $\% 27.3$ ü A grubunun özelliklerini taşımaktaydi. Siklus uzunluğu açısından değerlendirme yapıldığında hastaların \%31.8'inde $(\mathrm{n}=7)$ siklus normal (A=27-34 gün) bulundu. Hastaların $\% 40.9$ 'unun $(\mathrm{n}=9)$ birinci derecede akrabalarında tip 2 diyabetes mellitus (DM) öyküsü vardı. Hastaların FG skoru 16.3⒈26 (min:7-max:28) idi.

Tablo 1. Hastaların demografik özellikleri ve biyokimyasal verileri

\begin{tabular}{|l|c|c|}
\hline & Ortalama \pm SEM & (min-max) \\
\hline Yaş (yll) & $21.41 \pm 0.88$ & $(15-31)$ \\
\hline Menarş yaş1 (yl) & $13 \pm 0.3$ & $(9-16)$ \\
\hline VKI $(\mathrm{kg} / \mathrm{m} 2)$ & $27.8 \pm 1.6$ & $(0.5-47.5)$ \\
\hline Bel/Kalça oran1 & $0.78 \pm 0.01$ & $(100-150)$ \\
\hline Sistolik TA $(\mathrm{mmHg})$ & $118.8 \pm 2.4$ & $(60-100)$ \\
\hline Diastolik TA $(\mathrm{mmHg})$ & $77.3 \pm 2.3$ & $(67-102$ \\
\hline Açlı glukoz $(\mathrm{mg} / \mathrm{dl})$ & $84 \pm 1.28$ & $(70-124)$ \\
\hline 2.saat glukoz $(\mathrm{mg} / \mathrm{dl})^{*}$ & $95 \pm 2.8$ & $(3.2-23)$ \\
\hline İnsülin $(\mu \mathrm{U} / \mathrm{ml})$ & $12.1 \pm 1.2$ & $(0.6-4.8)$ \\
\hline HOMA-IR** & $2.3 \pm 0.25$ & \\
\hline
\end{tabular}

*75gr OGTT (mg/dl): 75 gr Oral Glukoz Tolerans Testi; **HOMA-IR: Homeostaz model değerlendirme metodu

Hastaların demografik özellikleri ve biyokimyasal verileri Tablo 1'de gösterilmiştir. Hastaların sadece 4’ü doğum ağırlığını biliyordu ve bunların doğum ağırlıkları 2850 ile $3400 \mathrm{gr}$ arasındaydı. Hastaların 8’i (\%36) obez ve 3’ü (\%13.6) fazla kilolu idi. Hastaların tamaminda LDL kolesterol ve trigliserid düzeyleri ile AST, ALT ve GGT düzeyleri normal bulunurken, 15 (\%68) hastada HDL kolesterol $50 \mathrm{mg} / \mathrm{dl}$ altındaydı. Tüm hastaların açlık glukoz, insülin ve 75 gr OGTT sonuçları normal sınırlar içerisindeydi.

\section{TARTIŞMA}

Polikistik over sendromu (PKOS) hormonal ve metabolik anormalliklerin olduğu komplex bir hastalıktır ${ }^{4}$. PKOS patogenezi tam olarak açılanamamakla birlikte multi-faktöriyel ve poligenik sebepler sorumlu tutulmaktadır. İnsülin etkisinde post-reseptör bağlanma defekti sonucu
Ancak hastaların \%41'inde insülin direnci vardı. Abdominal US'de hastaların \%72.7'sinde karaciğer normal bulunurken, 3 hastada (\%13.6) grade 1 ve 3 hastada (\%13.6) grade II hepatosteatoz saptand1.

Ultrasonografide (US) ortalama over volümleri sağda $11.6 \pm 1.12 \mathrm{ml}$, solda $11.5 \pm 1.01 \mathrm{ml}$ saptand. Hastaların hormon düzeyleri, insülin direnci durumları ve over volüm ölçümleri Tablo 2'de gösterilmiştir.

gelişen insülin direnci ve glukokortikoid reseptör (GR) protein konsantrasyonunda artış sorumlu tutulan mekanizmalardır ${ }^{5,11}$.

PKOS tanısı şu 3 kriterden ikisinin birlikte bulunmasiyla konulur: Klinik ve/veya biyokimyasal hiperandrojenizm, oligo-anovulasyon ve US'de polikistik overlerin görülmesi ${ }^{6,7}$. Insülin direnci ve insülin direncine kompanzatuar olarak gelişen 
hiperinsülinizm kardiyometabolik anormalliklere yol açmaktadır ${ }^{12}$.

Polikistik over sendromunda en s1k görülen hiperandrojenizm bulgusu hirsutizmdir. Hirsutizm modifiye Ferriman-Gallwey (m FG) metodu ile değerlendirilir ve toplam skorun 7 ve üstünde olması hirsutizm olarak kabul edilir ${ }^{8}$. Hastalarin \%6090'inda hirsutizm ve oligo-amenore beklenirken, bizim PKOS'lu hastalarımızın tamaminda hirsutizm ve $\% 55$ 'inde oligo-amenore saptanmıştır. Hastalarımızın yaş ortalaması düşük olduğundan infertilite oranları değerlendirilmemiștir.

Tablo 2. Hastaların hormon düzeyleri ile insülin direnci ve over volüm ölçümleri

\begin{tabular}{|c|c|c|}
\hline & $\begin{array}{c}\text { Normal bulgulara sahip hastalar } \\
\mathrm{n}, \%\end{array}$ & $\begin{array}{c}\text { Patolojik bulgulara sahip } \\
\text { hastalar n, \% }\end{array}$ \\
\hline $\begin{aligned} \text { VKI } & (\geq 30 \mathrm{~kg} / \mathrm{m} 2) \\
( & \geq 25 \mathrm{~kg} / \mathrm{m} 2)\end{aligned}$ & & $\begin{array}{l}8, \% 36 \\
3, \% 13.6\end{array}$ \\
\hline Homa-IR* & $13, \% 59$ & $9, \% 41$ \\
\hline Testosteron & $16, \% 72$ & $6, \% 28$ \\
\hline DHEAS4 & $18, \% 82$ & $4, \% 18$ \\
\hline 17-OH-Progesteron & $18, \% 82$ & $4, \% 18$ \\
\hline Ferriman-Gallwey (FG) & -- & $22, \% 100$ \\
\hline Sağ over volümü & $7, \% 32$ & $15, \% 68$ \\
\hline Sol over volümü & $9, \% 41$ & $13, \% 59$ \\
\hline US de PKO görünüm** & $9, \% 40.9$ (yok) & $13, \% 59.1$ (var) \\
\hline Siklus bozukluğu*** & $7, \% 31.8(\mathrm{~A})$ & $15, \% 68.2(\mathrm{~B}, \mathrm{C}, \mathrm{D})$ \\
\hline
\end{tabular}

*Homa-IR $\geq 2.24$ : Patolojik; FG $\geq 7$ : Hirsutizm; **US'de: Over volümü $>10 \mathrm{ml}$; Overlerde 12 veya daha fazla antral follikül olmasi: PKO ile uyumlu; ***Siklus düzeni: A:27-34 gün; B:35-44 gün; C:45-90 gün; D:>90 gün

Klinik bulgular PKOS’u düşündürdüğünde biyokimyasal ölçümler ve US bulguları ile tanıyı desteklemek gerekmektedir. Laboratuar incelemesinde over ve adrenal kökenli androjenik hormonlarda artış saptanabilir' ${ }^{6}$. Özellikle Luteinizan hormon (LH) amplitüdü ve serum konsantrasyonu artmış bulunabilmektedir. Artmış LH düzeyi overlerde c AMP artışı yaparak testosteron, DHEAS düzeylerinde artış ve seks hormonu bağlayıcı globulin (SHBG) düzeyinde azalmaya yol açarak, follikül gelişiminde duraklamaya neden olmaktadır. Teka hücrelerinde androstenedion ve 17-OHP artıșı da görülebilmektedir ${ }^{13,14}$. Fazla kilolu ve obez olan PKOS hastalarında SHBG düzeyinde görülen azalma, vücut yağ miktarındaki artıştan çok insülin direnci ve androjen artışı ile ilişkili gibi görünmektedir ${ }^{15}$.

Hastalarımızda SHBG düzeyleri ölçülememekle birlikte, \%72'sinde testosteron düzeyi, \%82'sinde DHEAS ve 17-OHP düzeyleri normal bulundu. Hastalarımızda hirsutizm oranının yüksekliğine rağmen androjen düzeylerinin genellikle normal bulunmasının muhtemel sebepleri, hastalarımızın bir kısminın hafif PKOS fenotipine sahip olmas1 veya bu hastalarda ovulatuar PKOS ihtimali olabileceğidir. Çünkü PKOS'lu olguların \%7585'inde menstrual bozukluk beklenmesine rağmen, oligo-amenoreik PKOS olgularında siklusların
$\% 30$ 'u ovulatuardır ${ }^{16}$. PKOS'ta ovulasyon bozukluğunun gelişmesi için tek başına hiperandrojenemi varlığından ziyade, hiperandrojenemi ve orta-şiddetli hiperinsülineminin kombine etkisi gerekmektedir ${ }^{15,16}$

PKOS hastalarında US değerlendirmesinde 12 veya daha fazla antral follikül olması ve/veya artmış over volümü $(>10 \mathrm{ml})$ PKO olarak tanımlanmaktadır ${ }^{17}$. Hastalarımızın US incelemesinde sağ over volümü 15 hastada (\%68) ve sol over volümü 13 hastada (\%59) $10 \mathrm{ml}$ ve üzerinde bulunmuştur. Ayrıca US'de overlerde $\mathrm{PKO}$ görünümü 12 hastada (\%54.5) saptanmıştır. Hastalarımızın bu sonuçları genel olarak literatür ile benzerlik göstermektedir. Unutulmamalıdır ki, PKOS tanısı düşünülen hastaların önemli bir kısmında overlerde PKO görünümü saptanamadığı gibi, sağlıklı kadınlarda da $\% 20$ oraninda ultrasonografik olarak PKO görünümü bulunmaktadır ${ }^{8,16}$.

Birçok PKOS'lu hastada abdominal obezite ve insülin direnci görülmekte ve bu kadınlarda bozulmuş glukoz toleransı ve tip 2 DM riski artmaktadır. Ayrıca dislipidemi, hipertansiyon, endotelyal disfonksiyon ve inflamasyon sonucunda kardivasküler risk artışı saptanmaktadır ${ }^{2,12}$. Patogenez tam olarak açıklanamamakla birlikte insülin direncinin kritik bir role sahip olduğu düșünülmektedir ${ }^{3}$. İnsülin direnci PKOS’lu 
kadınlarda diğer kadınlara göre 2-3 kat daha fazla beklenmektedir. Özellikle PKOS'u olan obez kadınlarda PKOS'u olmayan obezlere göre insülin direnci daha sik görülmektedir ${ }^{13}$. PKOS'u olan ve 40yaş üstündeki kadınlara, ailesel tip $2 \mathrm{DM}$ ve gestasyonel DM öyküsü olanlara ve tüm obez kadinlara glukoz tolerans testi yapilmas1 önerilmektedir ${ }^{18,19}$. Serum insülin düzeyi ve insülin direncinin ölçümü rutin olarak gerekli görülmemektedir ${ }^{20}$. Çalışmamızda hastaların tamamına 75 gr OGTT yapılarak DM ve prediyabet araştırıldı ve hiç birinde patolojik sonuç saptanmadı. Hastalarımızın ortalama insülin düzeyleri $12.1 \pm 1.2 \mu \mathrm{U} / \mathrm{ml}$ idi ve hastaların \%41'inde insülin direnci olduğu görüldü. İnsülin direnci saptanan hastalarımızın tamamı obez veya fazla kiloluydu.

PKOS hastalarında insülin direnci ve hiperinsülinizm sonucunda ortaya çıkan dislipidemi, hipertansiyon, kronik inflamasyon ve endotel disfonksiyonu gibi ciddi kardiyovasküler risk faktörleri daha erken yaşta ortaya çıabilmektedir ${ }^{19,20}$. Kendi hastalarımızı kardiyovasküler risk faktörleri açısından değerlendirdiğimizde, hiç birinde hipertansiyona ve inflamasyon göstergesi olan serum CRP yüksekliğine rastlamamakla birlikte, \%68'inde HDL kolesterol düşüklüğü $\quad(<50 \quad \mathrm{mg} / \mathrm{dl})$ ile karşılaşıldı. HDL kolesterol düşüklüğünün de kardiyovasküler risk için önemli bir parametre olduğu zaten bilinmektedir ${ }^{4,21}$.

Obezite PKOS hastalarında yaklaşı oranında görülmektedir. Obezitenin değerlendirilmesinde vücut kitle indexi (VKI), bel çevresi, bel-kalça oranı gibi yöntemler kullanılabilir21. Bel-kalça oranı kadınlarda obezite ile birlikte kardiyo-metabolik risk artışını gösteren bir yöntemdir ve kadınlarda bu oranın $\geq 0.85$ olması önemli risk artıșını gösterir 19,22. VKI'ne göre değerlendirmede 3 (\%13.6) hastamız fazla kilolu, 8 (\%36) hastamız obez grubuna girmekteydi. Hastalarımızdan sadece 4'ünde (\%18) bel-kalça oranı $\geq 0.85$ bulunmuştur. Sonuçta bizim hasta grubumuzda obezite oranı da beklenenden daha düşük bulunmuştur.

Sonuç olarak, PKOS tanısıyla izlediğimiz hastaların küçük bir grubunda yaptığımız bu çalışmada, grubun tamaminda hirsutizm olmasina rağmen, hiperandrojenizmin laboratuar bulguları, insülin direnci ve obezite oranı beklenenden daha düşük bulunmuştur. Ancak hastaların büyük kısmında abdominal US'de over volüm artışı ve PKO görünümü ile PKOS tanısı desteklenmiştir. PKOS’lu hastalarımızın daha doğru değerlendirilmesi için daha çok sayıda hastanın alındığı ve kontrollü klinik çalışmalar yapmamız gerektiğini düşünmekteyiz.

\section{KAYNAKLAR}

1. Abbot DH, Dumesic DA, Frank S. Developmental origin of polycystic ovary syndrome-a hypothesis. J Endocrinol. 2002;174:1-5.

2. Orio F, Vuolo L, Palomba S, Lombardi G, Colao A. Metabolic and cardiovascular consequences of polycystic ovary syndrome. Minerva Ginecol. 2008;60:39-51.

3. Khan KA, Stas S, Kurukulasuriya LR. Polycystic ovarian syndrome. J Cardiometab Syndr. 2006;1:12530.

4. Hoffman LK, Ehrmann DA. Cardiometabolic features of polycystic ovary syndrome. Nat Clin Pract Endocrinol Metab. 2008;4:215-22.

5. Nardo LG, Patchava S, Laing I. Polycystic ovary syndrome: pathophysiology, moleculer aspects and clinical implications. Panminerva Med. 2008;50:26778.

6. Yıldız BO. Polikistik over sendromu. Endokrinoloji Metabolizma ve Diyabet 2. Bask1 (Ed M Özata):3659. İstanbul Tip Kitabevi, İstanbul, 2011.

7. Rotterdam ESHRE/ASRM-sponsored PCOS Consensus Work-shop Group: Revised 2003 consensus on diagnostic criteria and long-term health risks related to policystic ovary syndrome. Fertil Steril. 2004;81:19.

8. Azziz R, Carmina E, Dewailly D, DiamantiKandarakis E, Escobar-Morreale HF, Futterweit W et al. The Androgen Excess and PCOS Society criteria for the polycystic ovary syndrome: the complete task force report. Fertil Steril. 2009;91:45688.

9. Legro RS: Polycystic ovary syndrome-the new millennium. Mol Cell Endocrinol. 2001;184:87.

10. Matthews DR, Hosker JP, Rudenski AS, Naylor BA, Treacher DF, Turner RC. Homeostasis model assessment: insulin resistance and beta cell function from fasting plasma glucose and insulin concentrations in man. Diabetologia. 1985;28:412-9.

11. Milutinović DV, Macut D, Božić I, Nestorov J, Damjanović S, Matić G. Hypothalamic-pituitaryadrenocortical axis hypersensitivity and glucocorticoid receptor expression and function in women with polycystic ovary syndrome. Exp Clin Endocrinol Diabetes. 2011;119:636-43.

12. Randeva HS, Tan BK, Weickert MO, Lois K, Nestler JE, Sattar N et al. Cardiometabolic aspects of the polycystic ovary syndrome. Endocr Rev. 2012;33:812-41.

13. Silfen ME, Denburg MR, Manibo AM, Lobo RA, Jaffe R, Ferin M et al. Early endocrine, metabolic, and sonographic characteristics of polycystic ovary 
syndrome (PCOS): comparison between nonobese and obese adolescents. J Clin Endocrinol Metab. 2003;88:4682-8.

14. Moran LJ, Teede HJ, Noakes M, Clifton PM, Norman RJ, Wittert GA. Sex hormone binding globulin, but not testosterone, is associated with the metabolic syndrome in overweight and obese women with polycystic ovary syndrome. J Endocrinol Invest. 2013;36:1004-10.

15. Lim SS, Norman RJ, Davies MJ \& Moran LJ. The effect of obesity on polycystic ovary syndrome: a systematic review and meta-analysis. Obesity Rev. 2013;14:95-109.

16. Amato MC, Guarnotta V, Forti D, Donatelli M, Dolcimascolo S, Giordano C. Metabolically healthy polycystic ovary syndrome (MH-PCOS) and metabolically unhealthy polycystic ovary syndrome (MU-PCOS): a comparative analysis of four simple methods useful for metabolic assessment. Hum Reprod. 2013;28:1919-28.

17. Conway G, Dewailly D, Diamanti-Kandarakis E, Escobar-Morreale HF, Franks S, Gambineri A et al. On behalf of the ESE PCOS Special Interest Group. The polycystic ovary syndrome: a position statement from the European Society of Endocrinology. www.eje-online.org 2014 European Society of Endocrinology.

18. Salley KE, Wickham EP, Cheang KI, Essah PA, Karjane NW, Nestler JE. Glucose intolerance in polycystic ovary syndrome - a position statement of the Androgen Excess Society. J Clin Endocrinol Metab. 2007;92:4546-56.

19. Wild RA, Carmina E, Diamanti-Kandarakis E, Dokras A, Escobar- Morreale HF, Futterweit W et al. Assessment of cardiovascular risk and prevention of cardiovascular disease in women with the polycystic ovary syndrome: a consensus statement by the Androgen Excess and Polycystic Ovary Syndrome (AE-PCOS) Society. J Clin Endocrinol Metab. 2010;95:2038-49.

20. Dewailly D, Lujan ME, Carmina E, Cedars MI, Laven J, Norman RJ et al. Definition and significance of polycystic ovarian morphology: a task force from the Androgen Excess and Polycystic Ovary Syndrome Society. Hum Reprod Update. 2014;20 334-52.

21. Dean D. Metabolic syndrome: time for action. Am Fam Physician. 2004;69:2875-82.

22. Metabolik Sendrom Araştirma Grubu. METSAR sonuçlari [Results of METSAR]. XX. Ulusal Kardiyoloji Kongresi. Antalya,2004. 